Submitted: 14.11.2013 Accepted: 28.11.2013
Słowa kluczowe

ultrasonografia centralnego układu nerwowego, ciemiączko przednie, badanie ultrasonograficzne trójwymiarowe,

krwawienia do układu komorowego, niemowlęta

\section{Ocena przydatności ultrasonografii 3D centralnego układu nerwowego u noworodków i niemowląt w ocenie krwawienia wewnątrzczaszkowego i jego następstw w badaniu przez ciemiączko przednie}

\author{
Usefulness of 3D sonography of the central nervous \\ system in neonates and infants in the assessment \\ of intracranial bleeding and its consequences \\ when examined through the anterior fontanelle
}

\section{Edyta Zielonka-Lamparska, Andrzej Paweł Wieczorek}

Zakład Radiologii Dziecięcej, Uniwersytet Medyczny w Lublinie, Lublin, Polska Correspondence: Zakład Radiologii Dziecięcej, Uniwersytet Medyczny w Lublinie, ul. Chodźki 2,20-097Lublin,e-mail: rtg@dsk.lublin.pl

\section{Streszczenie}

Ultrasonografia centralnego układu nerwowego, a szczególnie obrazowanie przez ciemiączko przednie, ze względu na możliwość wykonania badania przy łóżku pacjenta lub też w inkubatorze jest najczęściej stosowaną metodą diagnostyczną u noworodków i niemowląt z problemami neurologicznymi. Jednak pomimo powszechnego zastosowania metoda ta ma pewne ograniczenia. Są nimi płaszczyzny przekroju struktur mózgowia możliwe do uzyskania w obrazowaniu przez ciemiączko przednie. Celem pracy jest ocena przydatności ultrasonografii trójwymiarowej centralnego układu nerwowego u noworodków i niemowląt w ocenie krwawienia wewnątrzczaszkowego i jego następstw w badaniu przez ciemiączko przednie. Badaniami objęto 283 pacjentów leczonych w Dziecięcym Szpitalu Klinicznym Uniwersytetu Medycznego w Lublinie, u których istniały wskazania do badania przezciemiączkowego mózgu. Badanie ultrasonograficzne centralnego układu nerwowego w opcji dwu- i trójwymiarowej przeprowadzono u 283 pacjentów w wieku od 1 dnia do 18 miesięcy (średnio 2 miesiące). W badaniu ultrasonograficznym trójwymiarowym otrzymano 254 wyniki badań mające wartość diagnostyczną. Liczba zmian patologicznych wykrywanych w badaniu ultrasonograficznym była znamiennie statystycznie większa $(p=0,007)$ w badaniu ultrasonograficznym trójwymiarowym. W badaniach własnych największa czułość i istotna statystycznie przewaga metody trójwymiarowej nad dwuwymiarową dotyczyła krwawień do układu komorowego i krwawień wewnątrzmózgowych. Nowe techniki badania ultrasonograficznego, a wśród nich trójwymiarowego, niewątpliwie zwiększyły możliwości diagnostyczne ultrasonografii, zachowując przy tym wszystkie jej zalety. 


\author{
Key words \\ central nervous \\ system ultrasound, \\ anterior fontanelle, \\ three-dimensional \\ ultrasound, \\ intraventricular \\ hemorrhage, infants
}

\begin{abstract}
Due to the possibility to examine at the patient bedside or incubator, ultrasound imaging of the central nervous system, particularly through the anterior fontanelle, is the most common diagnostic examination performed in neonates and infants with neurological problems. Despite its common application, this method has certain limitations. These limitations are associated with cross-sections of the cerebral structures that can be obtained when examining through the anterior fontanelle. The aim of the paper was to assess the usefulness of three dimensional sonography of the central nervous system in neonates and infants in the assessment of intracranial bleeding and its consequences when examined through the anterior fontanelle. The study enrolled 283 patients treated at the Pediatric Teaching Hospital at the Medical University of Lublin in whom a transfontanelle cerebral examination was indicated. The two- and three-dimensional ultrasound examinations of the central nervous system were conducted in 283 patients aged from 1 day to 18 months (mean age: 2 months). 254 three-dimensional examinations were of diagnostic value. The number of detected pathological lesions was higher in a statistically significant way $(p=0.007)$ in the three-dimensional ultrasound examination. In the authors' own studies, the highest sensitivity and statistically significant superiority of the three-dimensional method over the two-dimensional one referred to detecting intraventricular or intracerebral hemorrhages. Novel techniques of ultrasound imaging, including the three-dimensional one, have undoubtedly increased the diagnostic possibilities of sonography and, at the same time, retained all its advantages.
\end{abstract}

\section{Wstęp}

Ultrasonografia (USG) centralnego układu nerwowego (CUN), a szczególnie obrazowanie przez ciemiączko przednie, jest najczęściej stosowaną metodą diagnostyczną u noworodków i niemowląt z obciążonym wywiadem okołoporodowym, wcześniactwem, niską masą urodzeniową, objawami infekcji, zaburzeniami neurologicznymi czy zaburzeniami układu krzepnięcia krwi ${ }^{(1)}$.

Badanie ultrasonograficzne jest nieinwazyjną metodą obrazowania, umożliwiającą diagnostykę przy łóżku pacjenta lub w inkubatorze. Pozwala zatem na uniknięcie transportu na inny oddział lub do innego szpitala, jak ma to miejsce w przypadku tomografii komputerowej (CT) lub - mniej dostępnego - rezonansu magnetycznego (MRI). Badanie USG jest również kilkakrotnie tańsze od wyżej wspomnianych $^{(2)}$. Ze względu na swoje liczne zalety ultrasonografia stała się najczęściej wybieraną metodą oceny CUN na oddziałach położniczo-noworodkowych.

Zmianami patologicznymi najczęściej diagnozowanymi w badaniu USG CUN są: krwawienia wewnątrzmózgowe lub dokomorowe, poszerzenie komór, leukomalacja okołokomorowa, malformacje naczyniowe, inne wady rozwojowe CUN, rzadziej guzy mózgu ${ }^{(2,3)}$. Pomimo powszechnego zastosowania metoda ta ma jednak pewne ograniczenia. Są nimi płaszczyzny przekroju struktur mózgowia możliwe do uzyskania w obrazowaniu przez ciemiączko przednie ${ }^{(4)}$. Uzyskanie wielu optymalnych dla postawienia prawidłowej diagnozy projekcji (takich jak przekroje skośne i osiowe) jest niekiedy znacznie utrudnione lub wręcz niemożliwe.

Obrazowanie trójwymiarowe (3D) pozwala uniknąć ograniczeń konwencjonalnej ultrasonografii (2D) - badany obiekt jest przedstawiany w przestrzeni w trzech wzajemnie do siebie prostopadłych płaszczyznach.

\section{Introduction}

Ultrasound imaging (US) of the central nervous system (CNS), particularly through the anterior fontanelle, is the most common diagnostic examination performed in neonates and infants with significant perinatal history, prematurity, low birth weight, symptoms of infections, neurological disorders or disorders in the coagulation system ${ }^{(1)}$.

Sonography is a non-invasive method of imaging enabling diagnosis at the patient's bedside or incubator. Thus, it does not necessitate transportation to a different ward or to a different hospital, as it may happen in the case of computed tomography (CT) or, a less available, magnetic resonance imaging (MRI). The US examination is also several times cheaper than the methods mentioned above ${ }^{(2)}$. Due to its numerous advantages, sonography became the most frequently selected method for the assessment of the CNS in obstetric and neonatal departments.

The most common pathologies in the CNS diagnosed by means of US examinations are: intracerebral or intraventricular hemorrhages, ventricular extension, periventricular leukomalacia, vascular malformations and other developmental anomalies of the CNS, more rarely - brain tumors $^{(2,3)}$. However, despite its common application, this method has certain limitations. They are connected with cross-sections of the cerebral structures that can be obtained when examining through the anterior fontanelle $\mathrm{e}^{(4)}$. Obtaining optimal slices for establishing a correct diagnosis (such as oblique and axial views) is sometimes hindered or even impossible.

Three-dimensional (3D) imaging allows for jumping over the shadows of conventional two-dimensional (2D) sonography - the examined structure is presented in three perpendicular planes. 
Wykonanie badania USG w opcji 3D jest mniej czasochłonne od tradycyjnego. Pojedyncza akwizycja odbywa się automatycznie i trwa najwyżej kilka sekund. Ma to szczególne znaczenie $\mathrm{w}$ diagnostyce chorych $\mathrm{w}$ ciężkim stanie oraz podatnych na wychłodzenie pacjentów leżących w inkubatorze.

Zebrane podczas badania dane trójwymiarowe można następnie edytować i opracować w sposób umożliwiający jak najlepsze uwidocznienie interesującej struktury lub zmiany patologicznej. Odbywa się ono na ekranie monitora aparatu ultrasonograficznego lub na dodatkowej roboczej stacji diagnostycznej, już bez udziału pacjenta. Możliwe są również pomiary objętości oparte na rzeczywistych danych objętościowych ${ }^{(5-9)}$.

Opracowywanie danych trójwymiarowych (postprocessing) jest najbardziej czasochłonnym etapem trójwymiarowego badania ultrasonograficznego.

Nowoczesna ultrasonografia 3D nie jest jednak pozbawiona wad - ściśle zależy od jakości wyjściowego obrazu dwuwymiarowego, co oznacza, że nie da się poprawić warunków badania, a tym samym złej jakości obrazu dwuwymiarowego. Niektóre artefakty (rozdzielczości, wzmocnienia, propagacji lub ruchowe) występujące podczas uzyskiwania obrazu 2D ulegają przełożeniu na obraz trójwymiarowy. Ponadto w rekonstruowanych przekrojach należy liczyć się z utratą rozdzielczości. Niemniej wraz z pojawianiem się coraz nowocześniejszych aparatów ultrasonograficznych i ta słabość metody jest stopniowo eliminowana ${ }^{(3,6)}$.

\section{Cel pracy}

Celem pracy jest ocena przydatności ultrasonografii 3D CUN u noworodków i niemowląt w ocenie krwawienia wewnątrzczaszkowego i jego następstw w badaniu przez ciemiączko przednie.

Mając na uwadze cel pracy, poszukiwano odpowiedzi na następujące pytania:

1. Jaka jest wartość badania 3D USG CUN w porównaniu z wartościami 2D USG w ocenie krwawienia wewnątrzczaszkowego?

2. Jakich informacji na temat krwawienia i jego następstw może dostarczyć badanie 3D USG w porównaniu $\mathrm{z}$ badaniem tomograficznym mózgu?

\section{Material i metodyka badań}

Badaniami objęto 283 pacjentów leczonych w Dziecięcym Szpitalu Klinicznym Uniwersytetu Medycznego w Lublinie, u których istniały wskazania do badania przezciemiączkowego mózgu. Badania przeprowadzono między 08.01.2007 a 29.10.2007 roku u pacjentów w wieku od 1 dnia do 18 miesięcy (średnio 2 miesiące).

Badania wykonano za pomocą aparatu Philips iU22 głowicą C8-5, a następnie przeprowadzono ocenę ultrasonograficzną 3D - głowicą endowaginalną 3D9-3V.
A 3D ultrasound examination is less time-consuming than the conventional one. A single acquisition is automatic and does not last longer than several seconds. This is of particular relevance in the diagnosis of patients in a severe condition and patients in incubators who are susceptible to hypothermia.

The three-dimensional data acquired during the examination may be subsequently edited and processed so as to obtain the best visualization of the required structures or pathological lesions. It takes place in the monitor of the ultrasound equipment or at an additional diagnostic workstation, without the presence of the patient. It is also possible to conduct volume measurements based on genuine volumetric data ${ }^{(5-9)}$.

The processing of three-dimensional data (postprocessing) is the most time-consuming part of a three-dimensional ultrasound examination.

Nevertheless, modern 3D sonography is not flawless - it is strictly dependent on the quality of the initial two-dimensional image, which means that the conditions of the examination, and bad quality of the 2D image, cannot be corrected. Some artefacts (resolution, enhancement, propagation or motion) which appear in the 2D image are transmitted into the 3D image. Furthermore, a loss of resolution must be taken into account in reconstructed images. Nonetheless, together with the appearance of more modern ultrasound systems, even this flaw is gradually being eliminated ${ }^{(3,6)}$.

\section{Aim of the paper}

The aim of this study was to determine the usefulness of $3 \mathrm{D}$ sonography of the CNS in neonates and infants in the assessment of intracranial bleeding and its aftereffects when examined through the anterior fontanelle.

It was attempted to answer the following questions:

1. What is the value of $3 \mathrm{D}$ sonography of the CNS compared to $2 \mathrm{D}$ US in intracranial hemorrhage assessment?

2. What information associated with hemorrhage and its aftereffects may be provided by 3D US examination when compared to brain $\mathrm{CT}$ ?

\section{Material and methods}

The study enrolled 283 patients treated at the Pediatric Teaching Hospital at the Medical University of Lublin in whom a transfontanelle cerebral examination was indicated. The study was performed between 8 January 2007 and 29 October 2007 on patients aged from 1 day to 18 months (mean age: 2 months).

The examinations were performed by means of Philips iU22 system with a C8-5 transducer and subsequently, a 3D assessment was performed with the use of 3D9-3V endovaginal probe. 
Badając struktury CUN obiema metodami ultrasonograficznymi, oceniano:

- wielkość i kształt układu komorowego;

- sploty naczyniowe w układzie komór bocznych;

- echogeniczność struktur mózgu;

- ewentualną obecność zmian ogniskowych i krwawień z uwzględnieniem ich wielkości i lokalizacji;

- przestrzenie płynowe przymózgowe;

- u pacjentów z zastawką - położenie drenu w drenażu komorowo-otrzewnowym.

Uzyskane obrazy oraz dane trójwymiarowe zapisywano na dysku aparatu ultrasonograficznego, a następnie na serwerze archiwizacyjnym DICOM na oddzielnej stacji. Służyła ona nie tylko do przechowywania i odtwarzania obrazów, ale również do przetwarzania i analizy danych trójwymiarowych.

U 23 pacjentów wykonano także tomografię komputerową mózgu.

Analizę statystyczną otrzymanych wyników przeprowadzono za pomocą programu Statistica 6.0 PL. Otrzymane wyniki przedstawiono jako:

- średnią arytmetyczną \pm odchylenie standardowe (SD) dla zmiennych o rozkładzie normalnym;

- medianę, wartość najmniejszą (min.) oraz wartość największą szeregu statystycznego (maks.) dla zmiennych o rozkładzie nienormalnym.

Zgodność rozkładu poszczególnych zmiennych w obrębie grup z rozkładem normalnym sprawdzono za pomocą testu $W$ Shapiro-Wilka. Ponieważ badane zmienne nie miały rozkładu normalnego, w dalszej analizie posłużono się testami nieparametrycznymi.

Wyniki przyjmowano jako istotne statystycznie przy poziomie istotności $p=0,05$.

\section{Wyniki}

\section{Badanie ultrasonograficzne CUN w opcjach 2D i 3D}

Badanie ultrasonograficzne CUN w opcji 2D i 3D wykonano u 283 pacjentów. W badaniu 3D USG otrzymano 254 wyniki badań mające wartość diagnostyczną.

Liczba wykrywanych zmian patologicznych była znamiennie statystycznie większa $(p=0,007)$ w badaniu ultrasonograficznym 3D. Dane te ilustruje ryc. 1.

U 214 spośród 254 (84,25\%) badanych wykazano zgodność rozpoznań ustalonych obiema metodami USG. U 40 (15,75\%) w opcji 3D USG rozpoznania różniły się znacznie $(p=0,007)$ w porównaniu z 2D USG. U $171(67,32 \%)$ pacjentów wynik badania był identyczny w obu opcjach USG. U 43 (16,93\%)
During both examinations of the CNS structures, the following were assessed:

- size and shape of the ventricular system;

- choroid plexuses of the lateral ventricles;

- echogenicity of the cerebral structures;

- presence of focal lesions and hemorrhages including their size and localization;

- pericerebral fluid spaces;

- in patients with a valve - the ventriculoperitoneal shunt placement.

The acquired 3D images and data were stored in the memory of the ultrasound system and subsequently, they were placed on the DICOM archive server at a remote station. It was not only used for storing and playback of the images, but also for postprocessing and analysis of the three-dimensional data.

Twenty-three patients also underwent computed tomography of the brain.

The statistical analysis of the obtained results was conducted with the use of Statistica 6.0 PL software. The outcomes were presented as:

- arithmetic means \pm standard deviation (SD) for variables with normal distribution;

- median, minimal (min.) and maximal (max.) values of the statistical series for variables with non-normal distribution.

The agreement of individual variables in the populations with normal distribution was checked by means of the Shapiro-Wilk test. Because the analyzed variables did not have the normal distribution, non-parametric tests were applied in further analysis.

The results were considered statistically significant at the level of $p=0.05$.

\section{Results}

\section{D and 3D ultrasound examinations of the CNS}

2D and 3D ultrasound examinations of the CNS were performed on 283 patients; 254 three-dimensional US examinations were of diagnostic value.

The number of detected pathological lesions was higher in a statistically significant way $(p=0.007)$ in the $3 \mathrm{D}$ ultrasound examination. These data are presented in fig. 1.

In 214 of $254(84.25 \%)$ patients, the agreement between the diagnoses established with both methods was demonstrated. In $40(15.75 \%)$ patients the diagnoses in 3D sonography were considerably different $(p=0.007)$ than those obtained in a 2D examination. In $171(67.32 \%)$ cases, the results of both examinations were the same. 


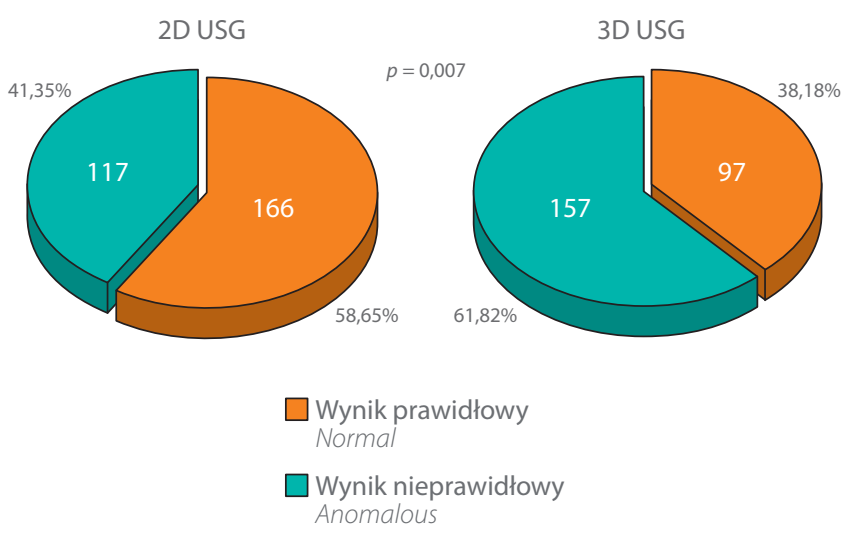

Ryc. 1. Porównanie wyników czułości 2D i 3D USG w wykrywaniu zmian patologicznych

Fig. 1. Comparison of the sensitivity of $2 D$ and $3 D$ sonography in detecting pathological lesions

badanych w opcji 3D USG pomimo zgodności rozpoznania z 2D USG uzyskano znacznie większy zakres informacji dotyczący obserwowanej patologii. Dane te ilustruje ryc. 2.

Liczba krwawień do układu komorowego i tkanki mózgowej zdiagnozowanych ultrasonograficznie była istotnie statystycznie wyższa $(p=0,0006)$ w badaniu 3D USG 72 spośród $254(28,34 \%)$ niż 2D USG - 50 spośród 283 $(17,66 \%)$ badanych.

Istotna statystycznie różnica czułości $(p=0,0003)$ dotyczyła wykrywania krwawień $\mathrm{I}^{\mathrm{o}}\left(\mathrm{IVH} \mathrm{I}^{\mathrm{o}}\right)$, które uwidoczniono u 2 spośród $283(0,7 \%)$ badanych w 2D USG i u 17 spośród 254 (6,69\%) w 3D USG.

U 5 spośród 19 (26,32\%) pacjentów, u których w 2D USG rozpoznano krwawienia II- IV ${ }^{\circ}$, w badaniu 3D USG zmieniono rozpoznanie dotyczące stopnia krwawienia lub jego lokalizacji (tab. 1).

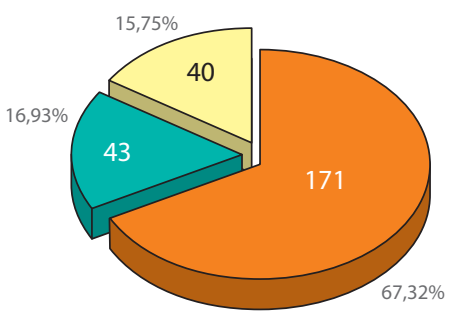

Identyczny wynik badania 2D i 3D USG The same results of $2 D$ and $3 D$ US examinations

$\square$ Większy zakres informacji w 3D niż w 2D USG More information acquired in the 3D than in 2D US examination

$\square$ Różnica rozpoznań w 2D i 3D USG

Different diagnoses in 2D and 3D US examinations

Ryc. 2. Ocena zgodności rozpoznań uzyskanych metodami $2 \mathrm{D}$ i 3D USG

Fig. 2. Assessment of the agreement of diagnoses established on the basis of $2 D$ and $3 D$ US examinations

Despite the agreement between the 2D and 3D examinations, in $43(16.93 \%)$ patients, 3D sonography revealed a considerable larger range of information concerning the observed pathology. These data are presented in fig. 2 .

The number of hemorrhages to the ventricular system and cerebral tissue diagnosed in sonography was higher in a statistically significant way $(p=0.0006)$ in a 3D examination -72 from among $254(28.34 \%)$ patients, than in a $2 \mathrm{D}$ examination -50 out of $283(17.66 \%)$ patients.

The statistically significant difference in sensitivity ( $p=0.0003$ ) was associated with grade I hemorrhage (IVH $\left.\mathrm{I}^{\circ}\right)$ which was visualized in 2 out of $283(0.7 \%)$ patients in a 2D examination and in 17 out of 254 (6.69\%) patients in a 3D examination.

In 5 out of $19(26.32 \%)$ patients in whom grade II-IV hemorrhage was diagnosed based on the $2 \mathrm{D}$ method, the

\begin{tabular}{|c|c|c|c|}
\hline \multicolumn{2}{|c|}{$\begin{array}{c}\text { Rozpoznanie w 2D USG } \\
\text { Diagnoses in 2D US }\end{array}$} & \multicolumn{2}{|r|}{$\begin{array}{c}\text { Rozpoznanie w 3D USG } \\
\text { Diagnoses in 3D US }\end{array}$} \\
\hline $\begin{array}{l}\text { Stopień krwawienia } \\
\text { Grade of hemorrhage }\end{array}$ & $\begin{array}{l}\text { Lokalizacja krwawienia } \\
\text { Localization of hemorrhage }\end{array}$ & $\begin{array}{l}\text { Stopień krwawienia } \\
\text { Grade of hemorrhage }\end{array}$ & $\begin{array}{l}\text { Lokalizacja krwawienia } \\
\text { Localization of hemorrhage }\end{array}$ \\
\hline $\mathrm{IVH} \|^{\circ}$ & $\begin{array}{l}\text { Wewnątrzkomorowo } \\
\text { Intraventricular }\end{array}$ & $\mathrm{IVH}^{\circ}$ & $\begin{array}{l}\text { Okolica bruzdy wzgórzowo-ogoniastej } \\
\text { Region of the thalamocaudate groove }\end{array}$ \\
\hline IVH III' & $\begin{array}{l}\text { Przyściennie w komorze } \mathrm{P} \\
\text { Mural in the right ventricle }\end{array}$ & $\mathrm{IVH}_{\mathrm{IV}}{ }^{\circ}$ & $\begin{array}{l}\text { Przyściennie w komorze P i śródmózgowo } \\
\text { Mural in the right ventricle and intracerebral }\end{array}$ \\
\hline IVH III ${ }^{\circ}$ & $\begin{array}{l}\text { Przyściennie w komorze } \mathrm{P} \\
\text { Mural in the right ventricle }\end{array}$ & $\mathrm{IVH}_{\mathrm{IV}}{ }^{\circ}$ & $\begin{array}{l}\text { Przyściennie w komorze P i śródmózgowo } \\
\text { Mural in the right ventricle and intracerebral }\end{array}$ \\
\hline IVH III' & $\begin{array}{l}\text { Obustronnie w komorze: } \\
\text { przyściennie i w okolicy splotów } \\
\text { Bilateral in the ventricle: } \\
\text { mural and in the region of plexuses }\end{array}$ & IVH III' & $\begin{array}{l}\text { W komorze P w okolicy otworu Monro } \\
\text { i w komorze III, w komorze L jak w 2D USG } \\
\text { In the right ventricle - in the region of the foramen } \\
\text { of Monro, and in the third ventricle; } \\
\text { in the left ventricle - as in 2D US }\end{array}$ \\
\hline IVH III & $\begin{array}{l}\text { Przyściennie w komorze L } \\
\text { Mural in the left ventricle }\end{array}$ & IVH III ${ }^{\circ}$ & $\begin{array}{l}\text { Okolica L otworu Monro } \\
\text { Region of the left foramen of Monro }\end{array}$ \\
\hline
\end{tabular}

Tab. 1. Zestawienie różnic w lokalizacji i klasyfikacji krwawień $I I-I V^{\circ}$ do CUN w $2 D$ i 3D USG u 5 pacjentów

Tab. 1. Differences in the localization and classification of hemorrhages (grade II-IV) to the CNS according to $2 D$ and $3 D$ ultrasound examinations in 5 patients 
W 2D USG ocena drenu zastawki komorowo-otrzewnowej była zadowalająca u 2 spośród 7 (28,57\%) pacjentów leczonych drenażem, natomiast niewystarczająco widoczna u $5(71,42 \%)$ badanych.

W badaniu 3D USG lokalizację drenu oceniano u 6 pacjentów z wodogłowiem. U wszystkich badanych (100\%) położenie drenu było zadowalająco widoczne.

U 2 spośród 14 pacjentów wykazujących cechy poszerzenia przestrzeni przymózgowych w 2D USG i 2 spośród 12 ocenianych w 3D USG wykryto hiperechogeniczne odbicia szeroką podstawą skierowane ku wewnętrznej powierzchni czaszki, co skierowało podejrzenie na obecność krwawienia do zbiorników przymózgowych. U jednego pacjenta zmiany te były zlokalizowane w okolicy ciemieniowo-potylicznej, u drugiego w okolicy skroniowo-potylicznej. Badanie 3D USG w obu przypadkach wykazało zgodność rozpoznań z 2D USG, dostarczyło jednak dodatkowych informacji dotyczących lokalizacji, dystrybucji i wielkości ogniska krwotocznego.

\section{Porównanie wyników badań ultrasonograficznych z CT CUN}

Dwudziestu trzech spośród $283(8,12 \%)$ pacjentów po wykonaniu badań USG wymagało pogłębienia diagnostyki CUN w tomografii komputerowej. U 20 spośród 23 (86,95\%) badanych uzyskano zgodny co do rozpoznania wynik z badaniami USG. U pozostałych $3(13,03 \%)$ powstały rozbieżności w rozpoznaniu. Polegały one na tym, że u 2 pacjentów nie uwidoczniono ognisk krwawienia widocznych w badaniach USG. U jednego nie potwierdzono ogniska krwawienia w okolicy komory bocznej, a w jego miejscu rozpoznano ognisko malacyjne. U jednego pacjenta w badaniu CT uzyskano prawidłowy obraz struktur mózgu.

\section{Omówienie wyników}

Badanie ultrasonograficzne ma zasadnicze znaczenie dla oceny struktur mózgowia u noworodków i niemowląt.

Nowe techniki USG, a wśród nich 3D USG, niewątpliwie zwiększyły możliwości diagnostyczne ultrasonografii, zachowując przy tym wszystkie jej zalety (takie jak łatwa dostępność, możliwość przeprowadzenia badania przy łóżku chorego oraz brak szkodliwości fal ultradźwiękowych). Dzięki nim możliwe jest wyeliminowanie ograniczeń obrazowania w opcji 2D USG, takich jak duża zależność od osoby wykonującej badanie i związane z tym trudności w ocenie przebiegu leczenia, niska powtarzalność uzyskanych wyników oraz mała dokładność wykonywania pomiarów objętości $i^{(3,8,10,11)}$.

U 32,68\% badanych uzyskano wyniki świadczące o przydatności dodatkowego obrazowania w opcji 3D USG. U $15,75 \%$ doszło do zmiany rozpoznania po wykonaniu 3D USG, zaś u pozostałych $16,93 \%$ badanie 3D USG dostarczyło dodatkowych informacji diagnostycznych. W 3D USG diagnosis concerning the grade or localization of bleeding was changed following a 3D examination (tab. 1).

In a $2 \mathrm{D}$ examination, the assessment of the ventriculoperitoneal valve was satisfactory in 2 out of 7 (28.57\%) patients with a shunt but in $5(71.42 \%)$ cases, the shunt was not sufficiently visible.

In a 3D US examination, the localization of the shunt was assessed in 6 patients with hydrocephalus. The localization of the shunt was visible in a satisfactory way in all patients $(100 \%)$.

In 2 out of 14 patients with signs of pericerebral space extension detected by means of 2D sonography and in 2 out of 12 patients examined with the use of the 3D method, hyperechoic reflections with a broad base directed towards the internal aspect of the cranium were visualized. This suggested the presence of bleeding to the pericerebral spaces. In one case, the lesions were localized in the parieto-occipital region and in the other - in the temporooccipital region. The diagnoses established based on 2D and 3D examinations were in agreement, but the 3D examination delivered additional information concerning the localization, distribution and size of the hemorrhagic focus.

\section{Comparison of ultrasound findings with the CT of the CNS}

The extended diagnosis in the form of a CNS assessment in computed tomography was necessary in 23 out of $283(8.12 \%)$ patients. In 20 out of $23(86.95 \%)$ cases, the outcome was in line with the US findings. In the 3 remaining patients (13.03\%) there were discrepancies in the diagnoses. In 2 patients, the hemorrhagic foci, previously visualized in the US examination, were not visible. In one patient, the presence of the hemorrhagic focus in the region of the lateral ventricle was not confirmed. A focus of malacia was detected instead. In one case, CT revealed normal image of the cerebral structures.

\section{Discussion}

Sonography is of key importance in assessing the cerebral structures in neonates and infants.

Novel US techniques, including the 3D US, have undoubtedly increased the diagnostic possibilities of sonography and retained all its advantages (such as accessibility, possibility of bedside examination and harmless character of ultrasonic waves). They allow to overcome limitation of the 2D sonography, such as considerable examiner-dependency and associated difficulty in treatment monitoring as well as low reproducibility of results and low accuracy of volumetric measurements ${ }^{(3,8,10,11)}$.

In $32.68 \%$ of patients, the results indicated that additional 3D ultrasound imaging is useful. In $15.75 \%$ of cases, the diagnosis was changed following a 3D US examination and in the remaining $16.93 \%, 3 \mathrm{D}$ sonography provided 
istotnie częściej wykrywano istniejące nieprawidłowości w porównaniu z 2D USG ( $p=0,007)$.

Większa czułość metody 3D USG wynika z możliwości powrotu do danych objętościowych zapisanych na dysku i poddania ich ponownej analizie. Pozwala to nie tylko na przeanalizowanie zapisanych danych warstwa po warstwie, ale również na wizualną poprawę jakości uzyskanych danych oraz ocenę parametryczną badanego obiektu, w tym również pomiary objętości oparte na rzeczywistych danych wolumetrycznych. W efekcie można wykryć zmiany patologiczne, które nie zostały zauważone wcześniej ${ }^{(4,6)}$.

Niewątpliwą zaletą jest szybkość wykonywania akwizycji danych w obrazowaniu 3D w porównaniu z czasem potrzebnym do wykonania badania w opcji 2D USG. Z drugiej strony więcej czasu należy poświęcić na obejrzenie i opracowanie badania 3D USG.

W badaniach własnych największa czułość i istotna statystycznie przewaga metody 3D nad 2D dotyczyła krwawień do układu komorowego i krwawień wewnątrzmózgowych. W badaniach własnych dzięki metodzie obrazowania 2D USG wykryto krwawienia do CUN u 17,66\% niemowląt; w 3D USG czułość była istotnie wyższa - ujawniono $28,34 \%$ krwawień $(p=0,0006)$.

W materiale własnym zaobserwowano, że obrazowanie 3D USG było szczególnie skuteczne w wykrywaniu subtelnych zmian, takich jak krwawienia podwyściółkowe (IVH $\left.\mathrm{I}^{\circ}\right)(6,69 \% \mathrm{w}$ stosunku do $0,7 \%$ badanych w $2 \mathrm{D}$ USG $p=0,0003)$ lub torbieli podwyściółkowych $(14,57 \%$ w stosunku do 10,24\% badanych w 2D USG $-p=0,026)$.

Uzyskane wyniki są zgodne z rezultatami innych badań, których autorzy opisują przewagę obrazowania 3D USG w różnicowaniu krwawień do warstwy rozrodczej wyściółki komór $\left(\mathrm{IVH} \mathrm{I}^{\circ}\right)$ ze splotami naczyniowymi. Ponieważ jedne i drugie są hiperechogeniczne w obrazie ultrasonograficznym oraz mają dość zbliżone umiejscowienie, pomocne w ich różnicowaniu mogą być dodatkowa projekcja osiowa oraz przekroje skośne $e^{(4,6)}$.

Nieliczne dane na temat zastosowania 3D USG w obrazowaniu mózgu dowodzą, że pokazuje ono nie tylko krwawienie - pozwala także na dokładną ocenę lokalizacji, stopnia krwawienia, ilości wynaczynionej krwi oraz dalszego rozwoju zmian krwotocznych ${ }^{(4)}$.

W przeprowadzonych badaniach 3D USG można dokładnie prześledzić dystrybucję skrzeplin w obrębie układu komorowego w stosunku do dróg odpływu płynu mózgowo-rdzeniowego - otworów Monro, nieco trudniej wodociągu mózgu. W materiale własnym zaobserwowano istotnie lepszą ( $p=0,013)$, w porównaniu z 2D USG, przydatność diagnostyki 3D USG do lokalizacji zmian krwotocznych. W rezultacie u 5 spośród 19 (26,32\%) pacjentów, u których w 2D USG rozpoznano krwawienia II-IV ${ }^{\circ}$, w badaniu 3D USG zmieniono rozpoznanie dotyczące stopnia krwawienia lub dokładniej oceniono jego lokalizację. U następnych 2 spośród 5 badanych w 2D USG additional diagnostic information. Moreover, in a 3D examination, the existing anomalies were detected more frequently when compared to 2D sonography ( $p=0.007)$.

The higher level of sensitivity of the 3D method results from the possibility to return to and re-analyse the volumetric data stored in the memory. Not only does it allow for the re-analysis of the stored data slice by slice, but also enables visual quality improvement and parametric assessment of the examined structure, including volume measurements based on genuine volumetric data. As a result, one may detect pathological lesions which were not detected earlier ${ }^{(4,6)}$.

An undoubted advantage is fast acquisition of data in 3D imaging in comparison to the time needed to conduct a 2D US examination. On the other hand, more time is needed for processing and analyzing the 3D image.

In the authors' own studies, the greatest sensitivity and statistically significant superiority of the 3D method over the $2 \mathrm{D}$ one referred to intraventricular or intracerebral hemorrhages. In the authors' own studies, 2D sonography visualized bleeding to the CNS in $17.66 \%$ of infants; in the 3D examination, the sensitivity was significantly higher $28.34 \%$ of hemorrhages were detected $(p=0.0006)$.

In the authors' own material, it was observed that a 3D US examination was more effective in visualizing subtle changes, such as subependymal hemorrhage $\left(\mathrm{IVH} \mathrm{I}^{\circ}\right)(6.69 \%$ compared to $0.7 \%$ of cases detected in a $2 \mathrm{D}$ examination $-p=0.0003$ ) or subependymal cysts ( $14.57 \%$ compared to $10.24 \%$ of cases detected in a $2 \mathrm{D}$ examination $-p=0.026$ ).

The outcomes of this study are in line with the results of other studies whose authors report the superiority of 3D imaging in differentiating hemorrhages to the germinal matrix $\left(\mathrm{IVH} \mathrm{I}^{\circ}\right)$ with choroid plexuses. Since they are both hyperechoic in the ultrasound image and have similar localizations, their differentiation may be facilitated by an additional axial projection or oblique views ${ }^{(4,6)}$.

A low number of data concerning the application of $3 \mathrm{D}$ sonography in brain imaging reveal that it shows not only bleeding, but also allows for an accurate assessment of localization, grade of hemorrhage, amount of extravasated blood and further development of hemorrhagic lesions ${ }^{(4)}$.

In 3D US examination, it is possible to thoroughly evaluate the distribution of thrombi within the ventricular system and their relation to the ways of cerebrospinal fluid's circulation - the foramina of Monro, or, which is slightly more difficult, the cerebral aqueduct. In the authors' own material, the usefulness of 3D diagnosis was judged as significantly superior ( $p=0.013$ ) to the $2 \mathrm{D}$ sonography in determining the localization of hemorrhagic lesions. As a result, in 5 out of $19(26.32 \%)$ patients in whom grade II-IV hemorrhage was diagnosed based on a 2D examination, the diagnosis concerning the grade or localization of bleeding was changed following a 3D examination. In further 2 out of 5 patents, 2D examinations revealed hydrocephalus 
stwierdzono wodogłowie i IVH III ${ }^{\circ}$ oraz niezbyt istotną lokalizację skrzeplin w układzie komorowym. Po prześledzeniu u tych pacjentów dystrybucji skrzeplin w układzie komorowym uwidoczniono ich niekorzystną lokalizację w stosunku do dróg odpływu płynu mózgowo-rdzeniowego. U jednego badanego skrzeplina obejmowała lewy otwór Monro, u drugiego blokowała prawy otwór Monro, przechodząc do komory III. W obu przypadkach diagnoza była zdecydowanie łatwiejsza dzięki dostępności płaszczyzny osiowej, na której można najlepiej uwidocznić połączenie komór bocznych z komorą III przez parzyste otwory Monro (ryc. 3).

U obu pacjentów wykazujących IVH III $^{\circ}$ w badaniu USG wykonano CT mózgowia, uwidaczniając cechy aktywnego przesiąkania okołokomorowego świadczące o wzmożonym ciśnieniu w układzie komorowym mózgu. Natomiast $\mathrm{u}$ żadnego $\mathrm{z}$ nich badanie $\mathrm{CT}$ nie potwierdziło informacji o obecności krwawienia wewnątrzkomorowego, mimo że w jednym przypadku CT wykonano po 4, a w drugim po 12 dniach od badania USG. Z tego względu trudno zgodzić się z opinią autorów twierdzących, że CT mózgu doskonale obrazuje krwawienia dokomorowe lub śródmózgowe (przynajmniej nie w każdej sytuacji). Jednak nie można zaprzeczyć, że CT lepiej niż każde badanie USG pokazuje objawy wzmożonego ciśnienia śródczaszkowego, przesiąkanie okołokomorowe lub zagrożenie wgłobieniem ${ }^{(2,12)}$.

Oceniając czułość metody obrazowania, w tym USG i CT, w wykrywaniu zmian patologicznych, należy uwzględnić jakość aparatu, wielkość zmiany, doświadczenie osoby wykonującej badanie, a w przypadku CT również protokół, według którego przeprowadzono badanie. and $\mathrm{IVH}_{\mathrm{III}}{ }^{\circ}$ and insignificant localization of thrombi in the ventricular system. Following evaluation of the blood clots distribution in the ventricular system, their unfavorable localization with respect to the ways of cerebrospinal fluid's circulation was demonstrated. In one of the patients a blood clot involved the left foramen of Monro and in the other, it blocked the right foramen and entered into the third ventricle. In both cases, the diagnosis was facilitated by the axial plane, in which the connection of the lateral ventricles with the third ventricle by the paired foramina of Monro is best visualized (fig. 3).

In both patients with $\mathrm{IVH} \mathrm{III}^{\circ}$ in the US examination, a cerebral CT scan was performed. It visualized the features of active periventricular transudation resulted from increased pressure in the ventricular system. However, a CT examination did not confirm the presence of intraventricular hemorrhage in either case even though in one patient, CT was performed after 4 days and in the second case - after 12 days of the ultrasound-based diagnosis. Therefore, it is difficult to concur with the opinion of the authors who claim that cerebral $\mathrm{CT}$ is the best tool for visualizing intraventricular or intracerebral bleeding (at least not in every situation). It cannot be denied, however, that CT is superior to any US examination in revealing the signs of increased intracranial pressure, periventricular transudation or herniation risk $^{(2,12)}$.

When assessing the sensitivity of the imaging method, including US and CT, in detecting pathological lesions, one should take into consideration the quality of the equipment, size of the lesion, experience of the examiner and, in the case of $\mathrm{CT}$, also the protocol according to which the examination is performed.

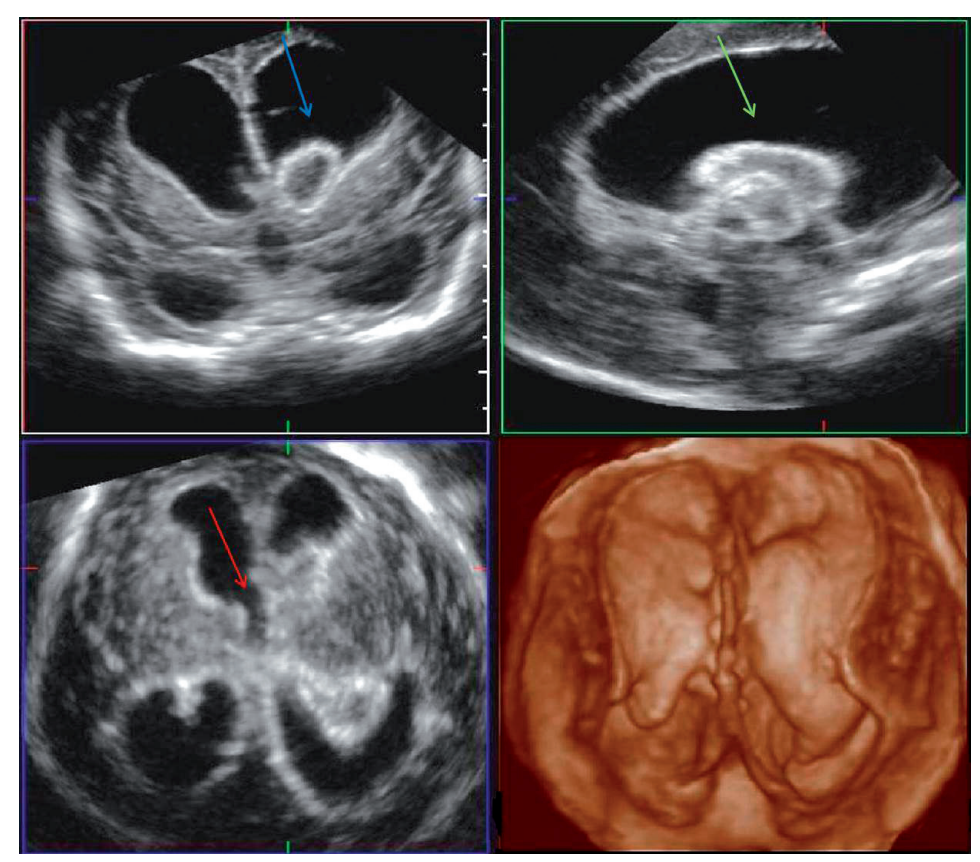

Ryc. 3. 3D USG: wodogłowie pokrwotoczne. Skrzeplina blokująca prawy otwór Monro (niebieska strzatka), przechodzaca do komory III (zielona strzatka). Lewy otwór Monro (czerwona strzatka)

Fig. 3. 3D US: post-hemorrhagic hydrocephalus. A thrombus blocks the right foramen of Monro (blue arrow) and enters into the third ventricle (green arrow). The left foramen of Monro (red arrow) 
W obu przypadkach skrzepliny o średnicy 7 i $15 \mathrm{~mm}$ nie były widoczne w badaniu CT. Przyczyną mogła być zbyt mała gęstość tych zmian pokrwotocznych lub protokół badania - nieuwidocznienie mniejszej zmiany może wiązać się $\mathrm{z}$ wartością przesunięcia stołu wynoszącą $5 \mathrm{~mm}$. U pacjenta z krwawieniem do komory III należy również brać pod uwagę możliwość ustąpienia zmiany po upływie 12 dni.

Poza badaniami CT przeprowadzonymi u 23 pacjentów, u których istniały wskazania do pogłębienia diagnostyki, nie było innej możliwości zrewidowania rozpoznań ustalonych na podstawie badań 2D i 3D USG. We własnej grupie badanych wyniki weryfikowało badanie 3 D USG - pozwala na zgromadzenie danych z badanego obszaru mózgowia i ich późniejszą ocenę.

W badaniu 3D USG na ekranie monitora w tym samym czasie widoczne są przekroje: wieńcowy, strzałkowy i poprzeczny (aksjalny), ponadto umożliwia ono rekonstrukcję objętościową badanej struktury (rendered view), co ułatwia przestrzenną lokalizację zmiany lub też struktury anatomicznej. W ocenie zespolenia komorowo-otrzewnowego ważne jest określenie położenia końca drenu - czy nie uległ on przemieszczeniu poza układ komorowy. W 2D USG na przekrojach strzałkowych końcówka drenu może być równoległa do wiązki ultradźwięków, a przez to słabo widoczna. W projekcji wieńcowej dostępnej w 2D USG trudno ustalić jej położenie w kierunku głowowo-ogonowym, ponieważ jest ona często widoczna na krótkim odcinku jako hiperechogeniczny punkt lub linia ${ }^{(13)}$.

Możliwości oceny położenia drenu w badaniu 3D USG ilustruje ryc. 4.

W materiale własnym uwidoczniono zbiornik przymózgowy - krwiaka w prawej okolicy ciemieniowo-potylicznej, który w przekroju osiowym dostępnym w opcji 3D wykazywał pełną zgodność obrazu z badaniem CT. Badanie CT potwierdziło obecność przymózgowego zbiornika płynowego położonego nadtwardówkowo, o współczynniku osłabiania krwi (ryc. 5).

Ważną zaletą ultrasonografii trójwymiarowej jest również możliwość przesłania zapisanych na dysku danych trójwymiarowych do innych specjalistów w celach konsultacyjnych, jak również ich wykorzystywania w nauczaniu specjalizujących się lekarzy oraz studentów.

\section{Wnioski}

1. 3D USG wykazuje istotnie większą czułość w wykrywaniu nieprawidłowości w obrębie struktur CUN u noworodków i niemowląt w porównaniu z 2D USG.

2. 3D USG dostarczyło dodatkowych (w porównaniu z 2D USG) informacji diagnostycznych u $43(16,93 \%)$ pacjentów. U kolejnych 40 (15,75\%) doprowadziło do zmiany rozpoznania.

3. Największa czułość diagnostyczna metody 3D USG dotyczy subtelnych zmian, takich jak IVH I ${ }^{\circ}$ czy torbiele podwyściółkowe, chociaż w badaniu 3D USG
In both cases, thrombi with the size of 7 and $15 \mathrm{~mm}$ were not visible in CT. This might have been caused by too low density of these post-hemorrhagic lesions or by the examination protocol - the failure to visualize smaller lesions may be associated with table movement by $5 \mathrm{~mm}$. In the case of hemorrhage to the third ventricle, the fact that the lesion may disappear within 12 days must also be considered.

Apart from the CT examination conducted in 23 patients, in whom extended diagnosis was indicated, there was no other way to review the diagnoses established by means of $2 \mathrm{D}$ and $3 \mathrm{D}$ ultrasound examinations. In the presented patients, the results were verified in the $3 \mathrm{D}$ ultrasound examination - it allows for collecting data from the studied cerebral region and enables their subsequent analysis.

In the 3D US examination, the monitor displays coronal, sagittal and axial planes simultaneously. Moreover, it enables volumetric reconstruction of the examined structure (rendered view), which facilitates the spatial localization of a lesion or a given anatomic structure. In the assessment of the ventriculoperitoneal shunt, it is necessary to determine the localization of its end to ensure that its position has not shifted beyond the ventricular system. In sagittal planes in 2D sonography, the end of the shunt may be parallel to the ultrasound beam, which makes it poorly visible. In the coronal plane, also available in 2D sonography, its cephalocaudal location is difficult to determine since it is frequently visible in a short fragment as a hyperechoic dot or line ${ }^{(13)}$.

The possibilities to assess shunt placement in 3D sonography is illustrated in fig. 4.

In the author's own material, the pericerebral collection was visualized - a hematoma in the right parieto-occipital region, which in the axial plane, available to obtain in the 3D sonography, was in a complete agreement with the CT image. The CT scan confirmed the presence of an epidural fluid collection with blood attenuation (fig. 5).

An important advantage of three-dimensional sonography is also the possibility to send the three-dimensional data stored in the memory to other specialists for consultation. Moreover, it is possible to use them for education of future physicians and students.

\section{Conclusions}

1. By comparison with $2 \mathrm{D}$ US, $3 \mathrm{D}$ sonography shows higher sensitivity in detecting anomalies within the CNS structures in neonates and infants.

2. $3 \mathrm{D}$ sonography provided additional diagnostic information (by comparison with 2D sonography) in 43 (16.93\%) patients. In further $40(15.75 \%)$ cases, it led to changing the diagnosis.

3. Although $3 \mathrm{D}$ US examination significantly more frequently visualized all hemorrhages to the ventricular system and cerebral tissue, the greatest diagnostic sensitivity of the 3D method refers to detecting subtle changes, such as IVH I or subependymal cysts. 


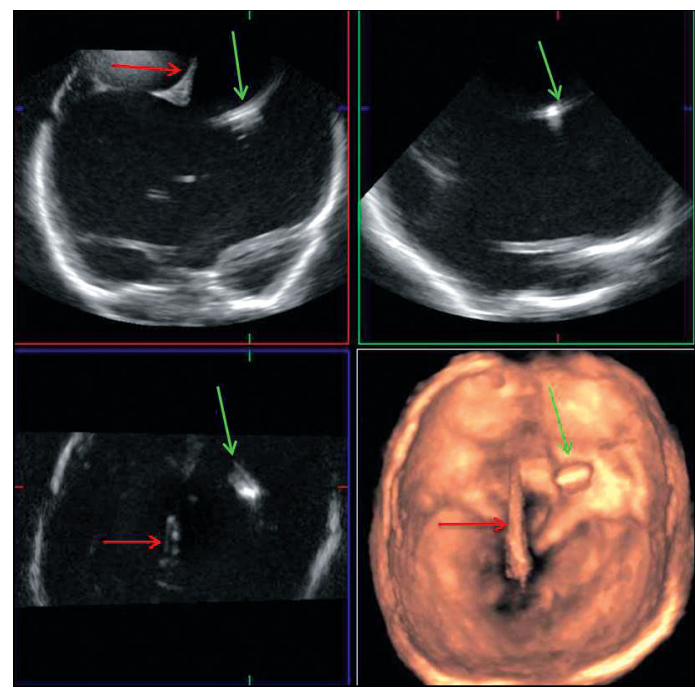

Ryc. 4. 3D USG: lokalizacja drenu (zielona strzatka) w wodogtowiu olbrzymim. Fragment sierpu mózgu (czerwona strzałka). Brak pofałdowania struktur mózgowych spowodowany uciskiem olbrzymiego uktadu komorowego najlepiej widoczny na rekonstrukcji objętościowej rendered view (prawy dolny obraz)

Fig. 4. 3D US: shunt localization (green arrow) in giant hydrocephalus. A fragment of the cerebral falx (red arrow). The lack of the folded structure of the brain caused by the compression of a huge ventricular system; best visible in the rendered view (bottom right image)

istotnie częściej wykrywano wszelkie krwawienia do układu komorowego i tkanki mózgowej.

4. 3D USG w porównaniu z badaniem 2D USG pozwala na istotnie lepszą ocenę rozległości zmian krwotocznych w obrębie struktur mózgu.

5. Badanie 3D USG pozwoliło na jednoznaczną ocenę położenia drenu w komorze u wszystkich pacjentów leczonych drenażem komorowo-otrzewnowym.

\section{Konflikt interesów}

Autorzy nie zgłaszaja zadnych finansowych ani osobistych powiqzań z innymi osobami lub organizacjami, które mogłyby negatywnie wptynać na treść publikacji oraz rościć sobie prawo do tej publikacji.

\section{Piśmiennictwo/References}

1. O'Hara SM: Extended field of view imaging: the big picture of pediatric patients. J Ultrasound Med 2002; 21: S38.

2. Barnes PD: Neuroimaging and the timing of fetal and neonatal brain injury. J Perinatol 2001; 21: 44-60.

3. Riccabona M, Fritz G, Ring E: Potential applications of three-dimensional ultrasound in the pediatric urinary tract: pictorial demonstration based on preliminary results. Eur Radiol 2003; 13: 2680-2687.

4. Salerno CC, Pretorius DH, Hilton SW, O'Boyle MK, Hull AD, James GM et al.: Three-dimensional ultrasonographic imaging of the neonatal brain in high-risk neonates: preliminary study. J Ultrasound Med 2000; 19: 549-555.

5. Fenster A, Downey DB: Three-dimensional ultrasound imaging. Annu Rev Biomed Eng 2000; 2: 457-475.

6. Riccabona M: Pediatric three-dimensional ultrasound: basics and potential clinical value. Clin Imaging 2005; 29: 1-5.

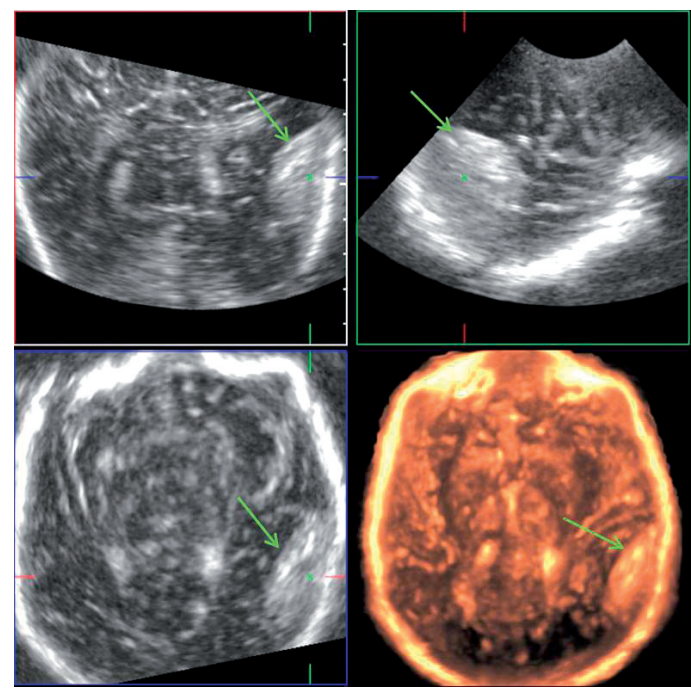

Ryc. 5. 3D USG: soczewkowatego kształtu krwiak nadtwardówkowy w prawej okolicy ciemieniowo-skroniowej (zielona strzatka)

Fig. 5. 3D US: lentiform shape of the epidural hematoma in the right temporoparietal region (green arrow)

4. By comparison with $2 \mathrm{D}$ sonography, the $3 \mathrm{D}$ method allowed for a significantly more accurate assessment of the extensiveness of hemorrhagic lesions within the cerebral structures.

5. 3D sonography enabled unambiguous assessment of the shunt position in the ventricle in all patients with ventriculoperitoneal shunt.

\section{Conflict of interest}

The authors do not report any financial or personal links with other persons or organizations that might negatively affect the content of this publication and claim authorship rights to this publication.

7. Riccabona M, Nelson TR, Weitzer C, Resch B, Pretorius DP: Potential of three-dimensional ultrasound in neonatal and paediatric neurosonography. Eur Radiol 2003; 13: 2082-2093.

8. Gordon I, Riccabona M: Investigating the newborn kidney: update on imaging techniques. Semin Neonatol 2003; 8: 269-278.

9. Szopiński K: Ultrasonografia 3D i 4D. Ultrasonografia 2004; 4 (15): 33-34.

10. Riccabona M: Advanced techniques in paediatric cranial ultrasound. J Ultrasound Med 2002; 21: S90.

11. Szopiński K, Rakoczy A, Słapa RZ: Podstawowe techniki prezentacji trójwymiarowej stosowane w diagnostyce obrazowej. Pol Merkur Lekarski 2002; $12: 5-10$.

12. Neil JJ, Inder TE: Imaging perinatal brain injury in premature infants. Semin Perinatol 2004; 28: 433-443.

13. Ichihashi K: Three-dimensional ultrasonography of hydrocephalus. J Med Ultrasonics 2005; 32: 181-185. 